\title{
Impact of Earthquakes on the Transportation Infrastructure of Indonesia: A Preliminary Study
}

\author{
Amirsardari, A. ${ }^{1}$, Sofi, M..$^{*}$, Lumantarna, E. ${ }^{1}$, Imran, I. ${ }^{2}$, and Duffield, C. ${ }^{1}$
}

\begin{abstract}
Indonesia is a high seismic region and one of the most vulnerable countries prone to experiencing damaging earthquakes. It is critical that lifeline infrastructure remain operational or is quickly remediated after an earthquake to minimise physical, social, and economical losses. Not much work has been carried out in understanding the effect of earthquakes on transportation infrastructure systems. This study aims to gain a better understanding of the impact of earthquakes on the transportation infrastructure in Indonesia. This is achieved by firstly reviewing the frameworks and tools for conducting seismic risk assessment of lifeline infrastructure. The critical components of the transportation system are then identified. Various forms of transportation infrastructure damage caused by earthquakes are discussed. An overview of the damaging earthquakes for the past 20 years is presented. Finally, conclusions and recommendations are provided about the future work required for conducting risk assessment of the transportation infrastructure in Indonesia
\end{abstract}

Keywords: Earthquake vulnerability; transportation system; infrastructure; Indonesia; seismic risk.

\section{Introduction}

Indonesia is one of the world's most vulnerable countries prone to natural disasters, including earthquakes, tsunamis, volcanic eruptions, and seasonal typhoons [1]. Natural disasters can have catastrophic impact on both a regional and national level as they cause physical, social, and indirect economic losses. Physical losses comprise of direct losses due to damage to the environment, including structures and infrastructures. Social losses include fatalities, injuries, emotional harm, and social unrest. Indirect economical losses account for losses induced postearthquake due to changes caused to daily activities of a region such as loss or reduced functionality of various systems and services.

Often, risk assessment is conducted to reduce losses and to mitigate the effect of natural disasters. Risk mitigation strategies are particularly important for lifelines; which are defined as systems which are necessary for human life and urban function [2]. An important lifeline infrastructure is the transportation system. Its performance is critical during and immediately after a disastrous event as they are required for emergency response and disaster relief efforts. In the long-term their performance is also important in order to minimise indirect losses since transportation systems provide the means for many important daily functions.

\footnotetext{
1 Department of Infrastructure Engineering, University of Melbourne, Parkville, 3010, AUSTRALIA

2 Bandung Institute of Technology, Bandung, Jl. Ganesha No.10, Lb. Siliwangi, Coblong, Bandung 40132, INDONESIA

*Corresponding author; email: massoud@unimelb.edu.au
}

Note: Discussion is expected before June, $1^{\text {st }} 2019$, and will be published in the "Civil Engineering Dimension", volume 21, number 2, September 2019.

Received 17 December 2018 revised 20 January 2019; accepted 19 March 2019
Most of the research that has been conducted thus far has focused on assessing the seismic performance of structures and point systems [3,4]. Less work has been conducted in understanding the effect of earthquakes on lifelines including transportation systems. One of the main reasons for this is due to the higher level of complexity involved in accurately conducting the seismic assessment of lifelines which often include both structural and geotechnical failure mechanisms and the interdependency of the various components of the system.

The aim of this study is to gain a better understanding of the impact of earthquakes on the transportation system in Indonesia. A brief review is provided of the frameworks for conducting seismic risk assessment which are particularly suitable for lifelines. The various components of the transportation system with relation to Indonesia are identified and the various forms of physical damage caused by earthquakes to the transportation infrastructure are discussed. Furthermore, an overview of the damaging earthquakes for the past 20 years is presented to provide an indication of the recent losses which have occurred in Indonesia due to the damage caused to transportation systems. Based on the findings, recommendations and conclusions are provided about the future work required for conducting risk assessment of the transportation system in Indonesia.

\section{Framework for Seismic Risk Assessment}

One of the first initiations for assessing the seismic vulnerability and impact of disruption of lifeline systems was in 1988 by the Applied Technology Council 
(ATC) with the support from the Federal Emergency Management Agency (FEMA). The research which was conducted is presented in ATC 25/FEMA 224 report; "Seismic vulnerability and impact of disrupttion of lifelines in the conterminous United States," [2]. The proposed framework, illustrated in Figure 1, consists of four steps: (i) development of a national lifeline inventory database, (ii) development of seismic vulnerability functions for each lifeline component/system (these functions describe the expected seismic performance of each lifeline as well as the time required to restore damaged infrastructure and facilities to their pre-earthquake capacity or usability, (iii) characterisation and quantification of the seismic hazard nationwide, and (iv) development of direct damage loss estimates (i.e., damage resulting directly due to ground shaking and other induced mechanisms) and indirect economic loss estimates (i.e., losses due to disruptions to lifeline functionality) for a particular earthquake scenario.

The framework presented in Figure 1 has formed the foundation of many other studies which have conducted assessment of lifelines. However, most of the research that has been conducted has focused on quantifying the direct losses due to earthquakes for isolated structures/infrastructure. It is only over the recent years that there has been a move to quantifying indirect losses and adopting network analysis methods to account for the interdependencies of network components [e.g., 5,6]. Indirect losses are dependent on residual-capacity or time-to-restoration curves which define the percentage of function restored as a function of time. For point systems (e.g., airports, schools, and hospitals), the time-torestoration curves are developed for isolated structures. However, for linear systems (e.g., roadways and railroads), the time-to-restoration curves require connectivity analyses and serviceability analyses [2].

To accurately conduct the risk analysis of lifeline infrastructures extensive spatial distribution data is required. This usually necessitates the implementation of a geographical information system (GIS). This has led to the development of numerous software packages and tools, such as Redars [7] and Hazus [8]. Redars is seismic-risk-analysis software package developed by the California Department of Transportation under the FHWA-MCEER Motorway Project (initiated in 1992) which is capable of estimating the structural and operational losses of transportation systems [5,6]. HAZUS methodology and software package has also been developed in the US, it is capable of predicting the direct physical damage and functionality of various transportation components, however, unlike REDARS, it is not able to account for the interdependence of various transportation systems and it is incapable of conducting network analysis [5]. Ina SAFE is a similar tool which has been developed for Indonesia by the Indonesian Government (BNPB), Australian Government, and the World Bank (GFDRR) [9]. While the platform is freely available the data required to assess the risk of transportation systems is incomplete and it does not incorporate the interdependence of various transportation components.

\section{Components of the Transportation Infrastruc- ture}

A critical part of accurately conducting risk assessment of the transportation system involves developing an inventory of the key components of the transportation infrastructure. The transportation system can be categorised into four groups: roadway, railroad, waterway, and air transportation system. The components of the various groups are described below in relation to Indonesia. It is noted that most of the information which is presented is obtained from the country report conducted by the Association of Southeast Asian Nations (ASEAN) Coordinating Centre for Humanitarian Assistance on Disaster Management (AHA Centre) and the Japan International Cooperation Agency [10].

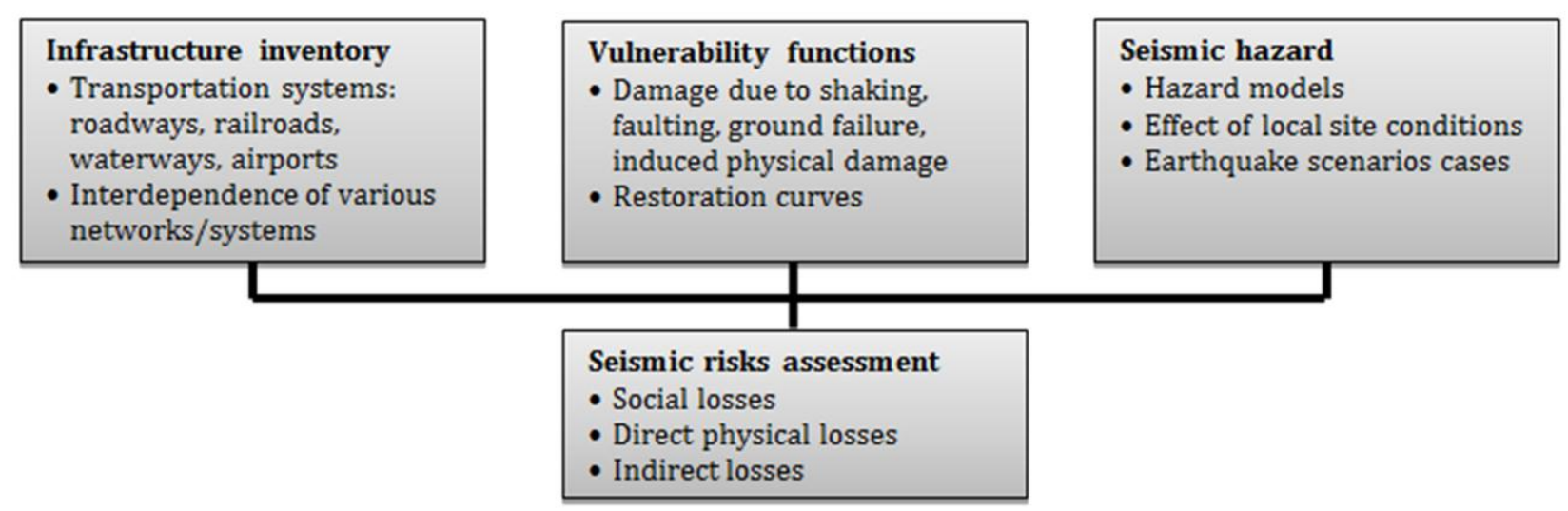

Figure 1. Framework for Conducting Seismic Risk Assessment of Lifelines, adapted from [2] 


\section{Roadway Transportation System}

The main components of the roadway transportation system include: paved and unpaved roads, bridges, overpasses, underpasses, tunnels, embankments, slopes, retaining walls, and maintenance facilities. The type of damage that can be experienced by roadways includes surface displacements, rupturing, liquefaction, slope instability, and earthquake induced flooding. In particular, bridges and overpasses have been identified to be the most vulnerable components of the transportation system [6] since in addition to ground surface and geotechnical failures they are also vulnerable to complete structural collapse. In Indonesia the total road length is estimated to be $497,000 \mathrm{~km}$, where approximately $8 \%$ are national roads, $11 \%$ are provincial roads, and $81 \%$ are regency roads. There are also around 93,000 bridges in Indonesia with a combined length of $1138 \mathrm{~km}$. Approximately $77 \%(734 \mathrm{~km})$ of the bridges are part of provincial, regency, and city roads, and the remaining $23 \%(404 \mathrm{~km})$ are part of nationnal roads.

\section{Railroad Transportation System}

In addition to the vulnerabilities of the roadway system, the railroad system is also vulnerable to vertical and horizontal track misalignments, structural damage to railroad buildings, and overturned railcars and locomotives. Furthermore, disruption may also occur due to traffic signal failure. Indonesia has a total train line of $6,720 \mathrm{~km}$, however, currently only $4,600 \mathrm{~km}$ of the train line is in use. The train lines are currently only operable in Java and Sumatra Island, with approximately more than two thirds

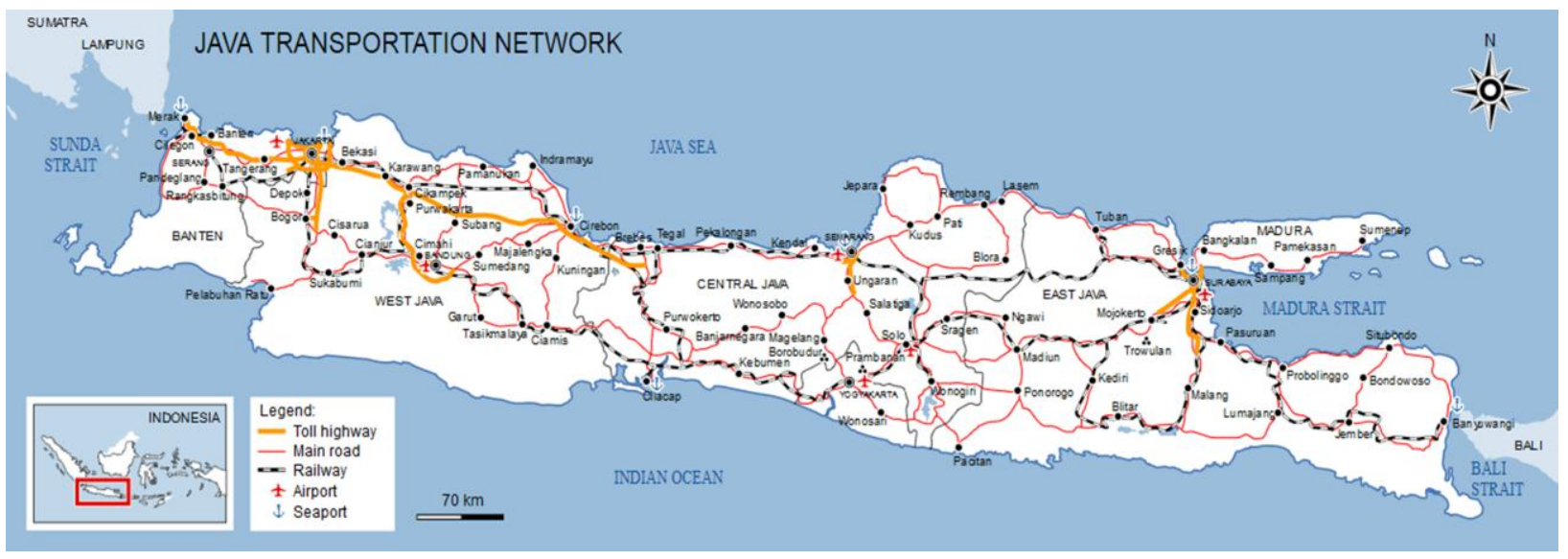

Figure 2. Transportation System of Java Island [10]

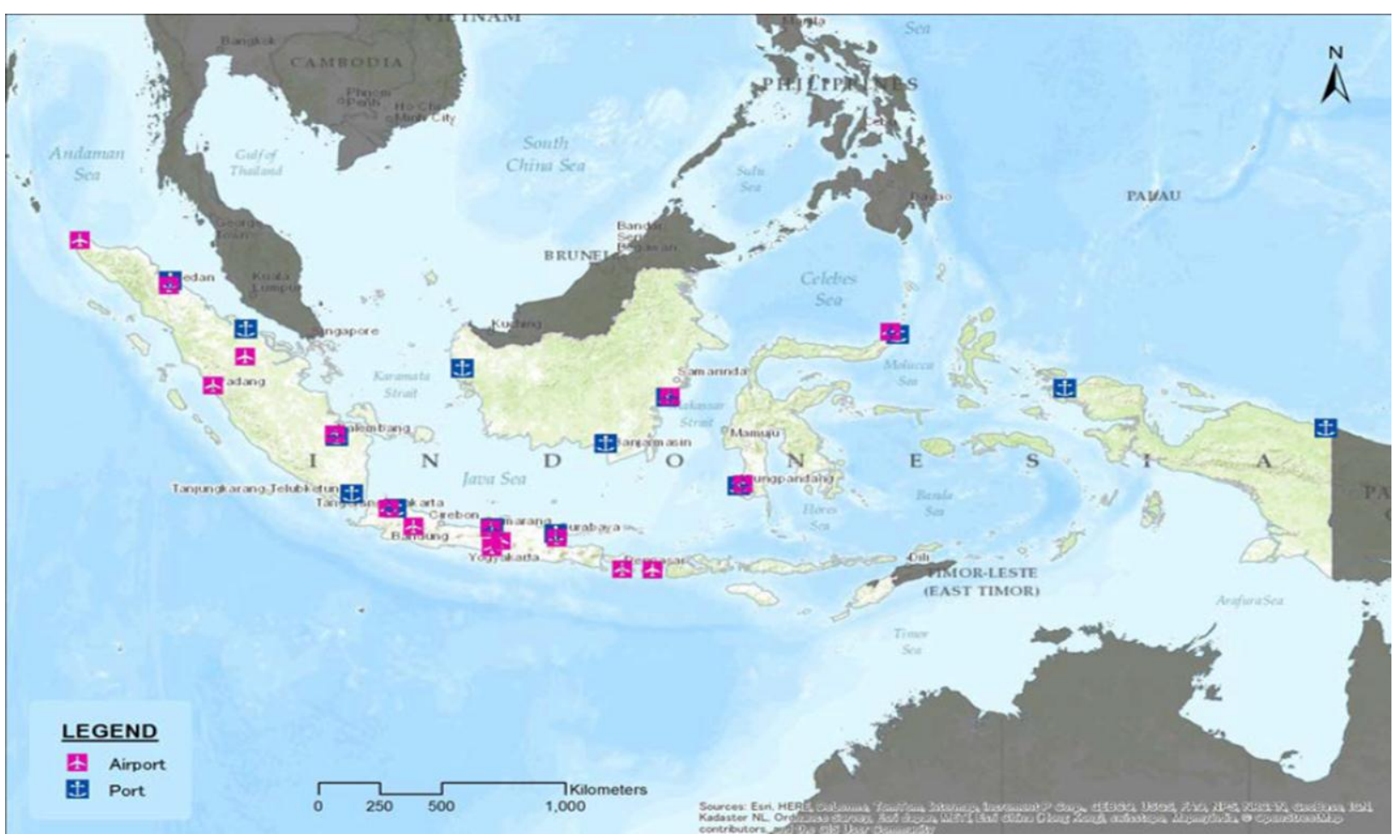

Figure 3. The Major Ports and Airports of Indonesia [10, 11] 
of the track lines being located in Java Island. An overview of transportation system of Java Island, including the railway system, is provided in Figure 2.

\section{Waterway Transportation System}

The main components of the waterway transportation system include: port facilities, rivers, canals, channels, banks, levees and dams. The waterway system can be categorised as coastal waterways; which includes traffic along the coasts, importing and exporting of freight from the sea, and inland waterways which includes traffic and movement of goods within a region. The maritime transportation system is particularly important for Indonesia since it consists of approximately 17,000 islands. In total, Indonesia has 300 public ports, of which 43 are international ports and 14 are ports assigned to ASEAN.

\section{Air Transportation System}

The critical components of the air transportation system includes: terminals, runways, power, communication and radar, and liquid fuel and transport. In total Indonesia has 187 airports for civil aviation usage and 16 of these are international airports. The location of the major ports and airports are provided in Figure 3.

\section{Physical Forms of Earthquake Damage}

It is critical that all the various forms of earthquake hazard are quantified when assessing the seismic risk of the transportation infrastructure. The main forms of direct physical damage caused by earthquakes, includes: ground shaking, ground failures, faulting, and induced physical damages.

\section{Ground Shaking}

Ground shaking can directly cause physical damage to various components of the transportation systems, including structural damage to facility buildings, bridges, storages, signal systems, overpasses, tunnels, and derailment of railcars and locomotives. Examples of damage caused by ground shaking from past earthquakes in Indonesia are provided in Figures 4 and 5 .

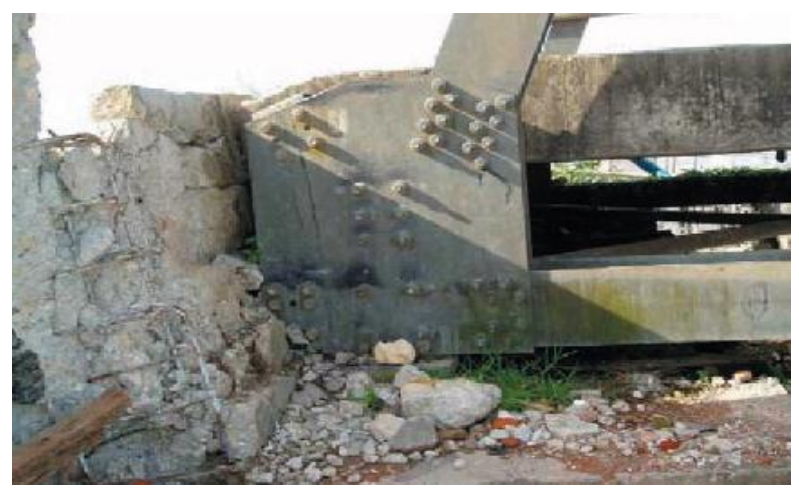

Figure 4. Displaced End Support of a Bridge in Nias [11]

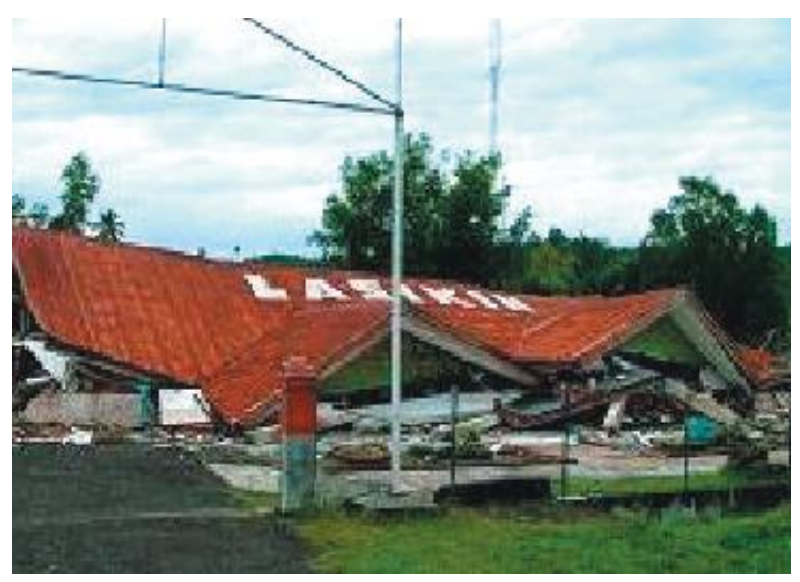

Figure 5. Collapsed Airport Terminal Building in Simeulue [11]

\section{Ground Failures}

There are various forms of ground failures which can occur due to earthquakes, including liquefaction and lateral spreading, slope instability, and subsidence. Liquefaction describes the process of the soil behaving in a liquid manner due to sudden loss of strength and stiffness due to the applied stresses under ground shaking. It induces failure to the foundations of the transportation components as the bearing strength is significantly reduced. Furthermore, there may also be lateral spreading where a layer of stable soil slides over the top of a liquefied layer [12]. Slope instability occurs due to the loss of the cohesive stability of the slope during ground shaking. It is particularly an issue for road and railway embankments. Earthquake induced rockfalls and landslides can significantly damage and block roadways. The shaking from earthquakes can cause land subsidence by settling and compacting unconsolidated soil. Furthermore, large areas of land can subside due to offsets of fault lines. Examples of ground failures observed in Indonesia due to various earthquake events are provided in Figures 6 to 9 .

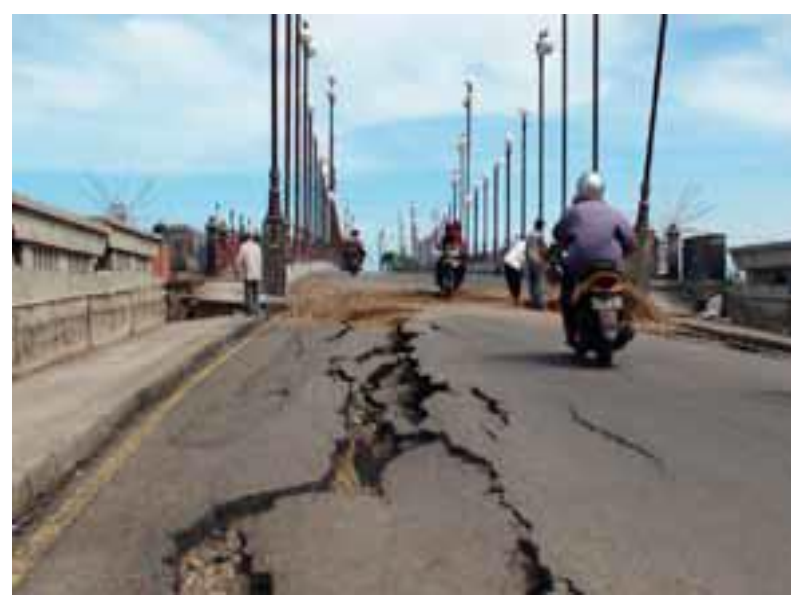

Figure 6. Damage Caused to an Approaching Ramp to Siti Nurbaya Bridge [13] 


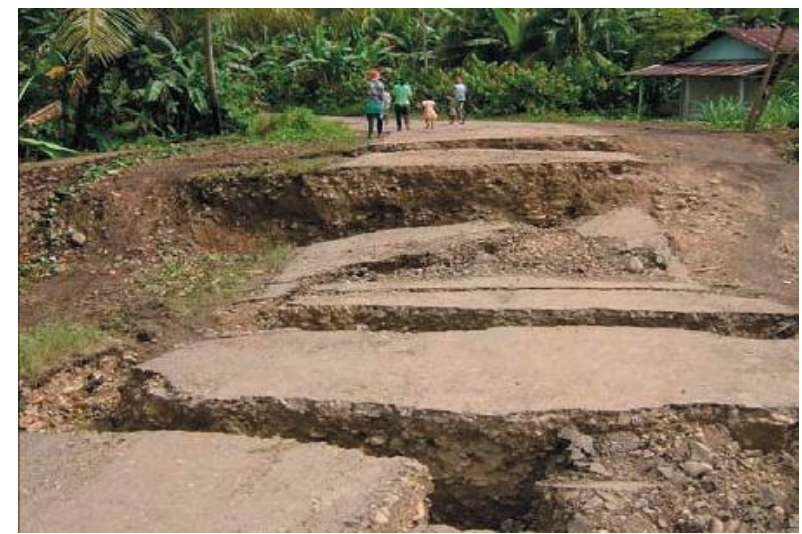

Figure 7. Cracks on an Unpaved Road due to Lateral Spreading, March 28 Nias \& Simeulue Earthquake [11]

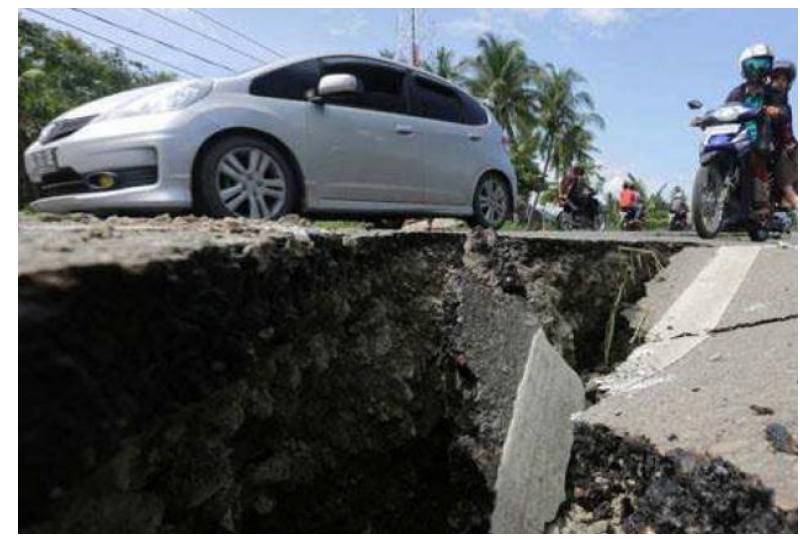

Figure 8. Cracks on the Road due to 2016 Pidie Jaya Earthquake [14]

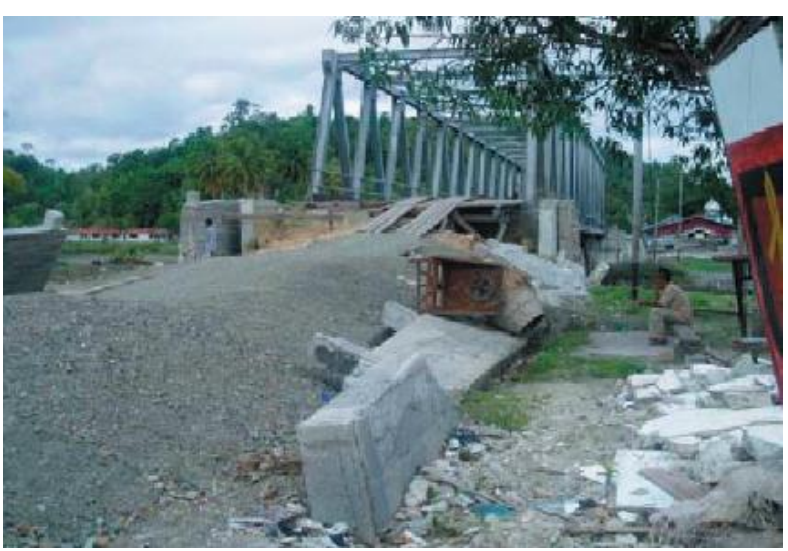

Figure 9. Settlement of a Bridge Approach in Simeulue [11]

\section{Faulting}

In high seismic regions earthquakes typically occur due to the rupturing of a fault because of built up of stresses in the crust. This causes large surface displacements which can cause significant damage to transportation systems which cross the rupture. For example, train track misalignment can occur and the separation of bridge piers. An example of significant damage caused to roadways due to fault rupture (and liquefaction) is illustrated in Figure 10.

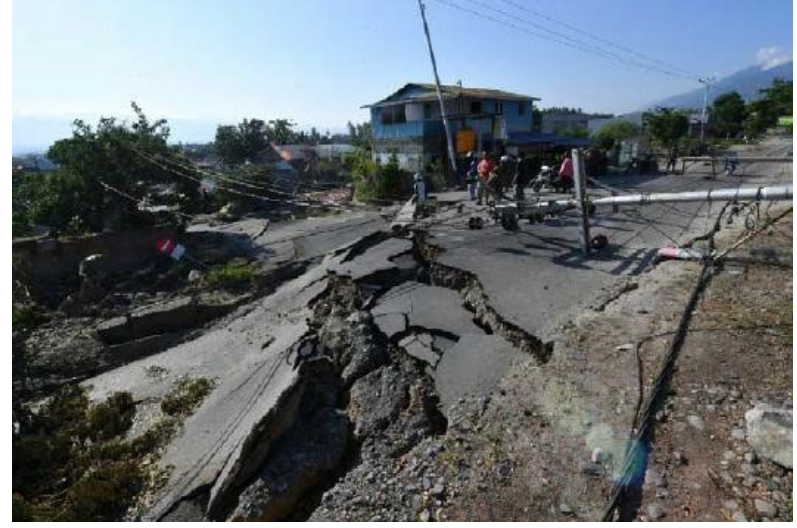

Figure 10. Damage to Roads due to Fault Rupture and Liquefaction, Palu Earthquake [15]

\section{Induced Physical Damages}

Induced physical damages due to an earthquake includes: tsunami, flooding, dam and levee failures, landslides, fires, and release of hazardous products. Indonesia is particularly vulnerable to experiencing tsunamis after an earthquake. Tsunamis can cause extensive damage, including washing out of bridge piers and embankments, derailment and overturning of railcars and locomotives. Dam and levee damages can also cause significant losses to the nearby community, especially during high water periods. Examples of damage caused by tsunamis in Indonesia are provided in Figures 11 and 12.

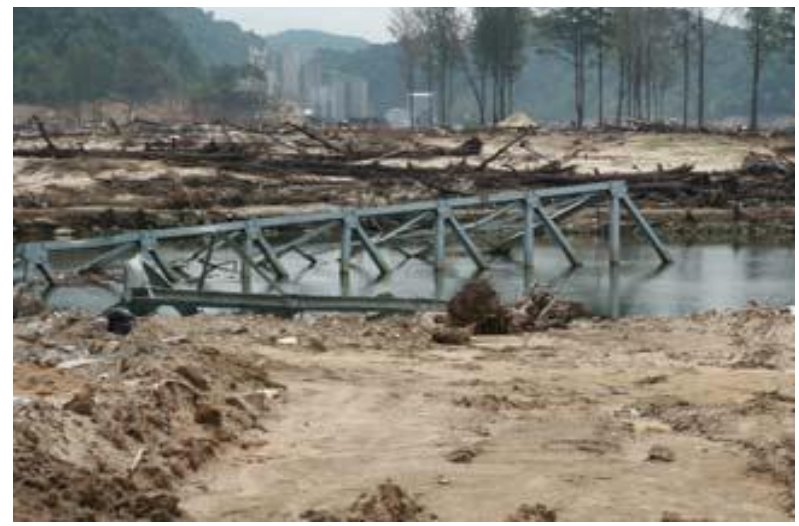

Figure 11. Steel Truss Bridge Swept off its Supports during the Aceh Earthquake [16]

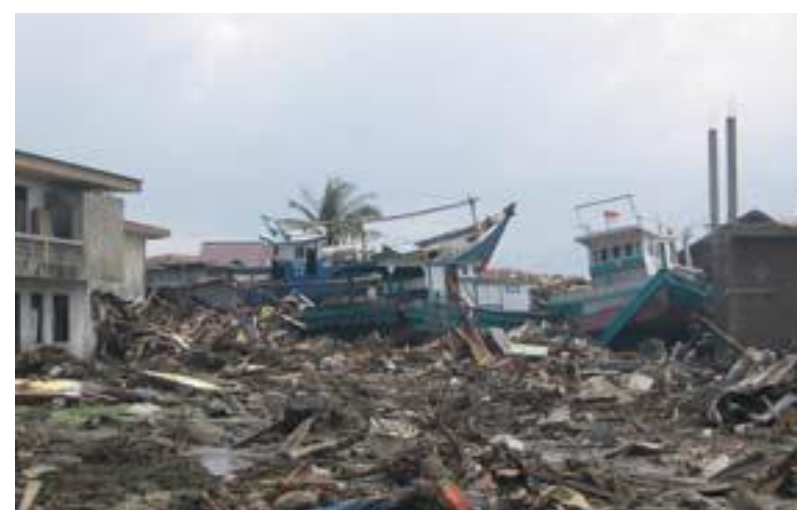

Figure 12. Debris Blocking Streets due to Damage Caused by Tsunami in Banda Aceh [16] 


\section{Review of Damage Caused by Previous Earth- quakes in Indonesia}

The following section provides an overview of the damaging earthquakes which have recently occurred in Indonesia. Detailed information about all of the earthquakes are not readily available, however, where possible information regarding the damage caused to the transportation system is discussed. The information presented assists in gaining a better understanding of the impact of earthquakes on the transportation infrastructure with respect to physical, social, and economical losses.

\section{Enggano-Bengkulu Earthquake (June 4, 2000)}

This earthquake occurred in south of Sumatra beneath the Indian Ocean at a depth of $33 \mathrm{~km}$ and had a magnitude of 7.9 [17]. Most of the damage occurred in the city and province of Bengkulu and the Enggano Island. In total, it resulted in 90 fatalities and over 2000 injuries from which approximately a thousand were reported as serious injuries [17]. A series of aftershocks continued for two weeks and eventually a second earthquake occurred with a similar magnitude and location. No tsunamis were generated by the earthquakes.

A detailed report about the damage caused by the earthquake was provided by the United Nation Disaster Assessment and Coordination (UNDAC) team [18]. The main damage was reported to be caused to houses, with 1800 houses reported as completely destroyed and 10,196 as seriously damaged. In terms of the transportation infrastructure, significant damage was caused to bridges with four bridges reported to be destroyed, 11 heavily damaged, and 20 lightly damaged. However, the bridges which were not collapsed were used after the earthquake. Most of the roads also remained operational although some sustained damage including cracking of the pavement, minor landslides and fallen rocks on the roadside. Some harbour facilities were also damaged. The Bengkulu airport remained fully operational and only suffered superficial damage to terminal buildings. The financial costs associated with the earthquake have not been reported.

\section{Aceh Earthquake (December 26, 2004)}

The Aceh earthquake was a magnitude 9.3 shallow earthquake with a depth of approximately $30 \mathrm{~km}$ which occurred due to rupturing of the subduction zone between the Indian plate and the Burma microplate [16]. It was followed by a series of very destructive tsunamis with wave heights exceeding $20 \mathrm{~m}$. Damage was caused to 19 countries including Indonesia, Malaysia, Myanmar, Thailand, Bangladesh, Sri Lanka, and India [16]. However, Banda Aceh suffered the most and the damage was due to both seismic excitations and tsunamis. The earthquake and the tsunami which followed caused more than 200,000 fatalities. The total cost of the earthquake has been approximated to be US $\$ 4.5$ billion (corresponding to 54\% regional GDP) [19]. Approximately $39 \%$ of the total loss was due to the damage caused to houses and buildings, $20 \%$ to the infrastructure, and the remaining costs due the losses caused to the productive sectors and cross sectoral [20]. More than $60 \%$ of the losses caused to the infrastructure was due to the damage caused to the transportation infrastructure from which $73 \%$ was due to direct losses and $27 \%$ due to indirect economical losses [20]. In addition to the collapse of many buildings, the land transportation system in Banda Aceh was completely disabled due to the tsunami. This significantly compromised disaster reliefs and response procedures. Many bridges had collapsed due to tsunami forces or had been swept off their piers and abutments, furthermore the main roads and small streets were completely destroyed or blocked due to debris of collapsed buildings and trees [16]. Interestingly, some piers and abutments were left undamaged (even though the bridge structure had been swept away) and they were utilised for the construction of new bridges during disaster relief efforts [16].

\section{Nias-Simeulue Earthquake (March 28, 2005)}

The Nias-Simeulue earthquake was of magnitude 8.7 and had a depth of approximately $30 \mathrm{~km}$ [21]. It was followed by a series of strong aftershocks and a local tsunami. It resulted in approximately 1000 fatalities and more than 61,000 injuries [11]. The costs associated with the earthquake and tsunamis have not been reported. Most of the transportation damage was caused to bridges, predominantly due to displacement of supports (30 to $100 \mathrm{~cm}$ ), settlement of bridge abutments, as well as differential settlement due to lurching, liquefaction, and uneven compaction [11].

\section{Yogyakarta and Central Java Earthquake (May 27, 2006)}

The Yogyakarta and Central Java earthquake was a shallow earthquake with a depth of $33 \mathrm{~km}$ and with a magnitude of 6.3 [22]. It resulted in 5,700 fatalities and more than 40,000 injuries, furthermore it was followed by Mount Merapi's volcanic activity [22] The total cost associated with the earthquake was approximated to be US $\$ 3.1$ billion (corresponding to $41 \%$ regional GPD), where $78 \%$ of the total cost was due to direct damage (i.e., costs associated with replacement and reconstruction) and $22 \%$ of the total cost was associated with economic losses (i.e., costs related to reductions in economic activities and in personal and family income post-earthquake) [19, 22]. 
The details of the damage caused by the earthquake are provided in the report prepared by the The Consultative Group on Indonesia [22]. Overall the damage was predominantly caused to houses and buildings. The impact of the earthquake on the transportation system was minimal and the recovery time was relatively quick. The cost associated with the transportation \& communication systems were reported to be only $0.3 \%$ of the direct damage cost and zero of the economic loss. However, minor damage was caused to a widespread of roads, bridges, mainline railway tracks and associated infrastructure (station buildings, signals and telecommunications), and localised damage to Yogyakarta's airport. The cause of damage was mainly due to minor subsidence and pavement deformation, longitudinal cracking of bridge decks, and unfastening of expansion joints.

\section{Pangandaran (West Java Province) Earth- quake (July 17, 2006)}

The Pangandaran earthquake was a magnitude 7.7 earthquake with a depth of $34 \mathrm{~km}$ [23]. It was followed by a tsunami which caused most of the damage to the Pangandaran region [23]. The perceived shaking intensity was low, however, significant displacement of the seabed occurred which caused the tsunami [23]. It resulted in the death of more than 660 people and caused injuries to more than 9,000 people [24]. The total cost was estimated to be US $\$ 44.7$ million [24]. Most of the damage was caused to low- to midrise buildings due to the tsunami only and only minor damage was caused to the lifeline infrastructure $[23,25]$

\section{Bengkulu Earthquake (September 12, 2007)}

The Bengkulu earthquake was a magnitude 8.4 earthquake and it was approximated to have a depth of $30 \mathrm{~km}$ [26]. It was followed by two large aftershocks (with magnitude 7.9 and 6.8) and a series of tsunamis [26]. In comparison to other earthquake of similar magnitudes the casualties was lower, with a fatality rate of 25 and 41 injuries. However, the economic loss was high, it has been estimated as US\$ 164 million [27]. Most of the damage was caused to houses. Moderate damage was caused to the transportation system, with most of the damage reported to be caused to the roads (along the shoreline); due to rupture, settlement due to landslides, liquefaction [27]. Furthermore, several major bridges were also damaged, due to settlement of piers and failure of abutments due to liquefaction [27]. However, the roads and bridges were accessible after the earthquake even though they were damaged.

\section{West Sumatra Earthquake (September 30, 2009)}

The West Sumatra earthquake was of magnitude 7.6 and had a depth of approximately $80 \mathrm{~km} \mathrm{[13].} \mathrm{It}$ resulted in the death of just under 1,200 people and a total cost of US $\$ 2.3$ billion, corresponding to $30 \%$ regional GPD [19]. Approximately $80 \%$ of the total cost was due to damages and losses associated with infrastructure; predominantly related to the collapse and damage of houses and buildings [28]. Minor damage was reported to be caused to the transportation infrastructure (roads and bridges); mainly due to landslides and ground settlements. However, the damaged caused to road segments was reported to make access to certain areas difficult and it also delayed the transportation of goods and services during disaster relief efforts [28]. Nevertheless, most roads were made accessible after a few days from the earthquake and priority of remediation was given to key roads in mountainous regions vulnerable to experiencing landslides, [28]. It is noted that even though the roads were re-opened, in some cases they were at risks of further failures especially due aftershocks or heavy rainfalls.

\section{Mentawai Earthquake (October 25, 2010)}

The Mentawai earthquake was a shallow earthquake with a depth of $21 \mathrm{~km}$ and a magnitude of 7.7 , it was also followed by a tsunami [29]. It resulted in the death of more than 445 people and more than 170 people were injured. The damage was mainly caused to houses, and no damage was reported to be caused to the transportation system [29].

\section{Aceh Earthquake (July 2, 2013)}

The Aceh earthquake which occurred in 2013 was a very shallow earthquake with a depth of only $10 \mathrm{~km}$ and a magnitude of 6.1 [30]. It resulted in 35 fatalities and 275 injuries. The damage was predominantly caused to buildings, including houses, schools, and mosques. Some damage was also caused to the transportation system; mainly due to landslides blocking the roads [30].

\section{Pidie Jaya, Aceh Earthquake (December 7, 2016)}

The Pidie Jaya earthquake was also another very shallow earthquake with a depth of $13 \mathrm{~km}$ and a magnitude of 6.5 [14]. It resulted in the death of 104 people and caused injuries to more than hundreds of people. Most of the damage caused by the earthquake was to buildings; however, moderate damage was also caused to roads and bridges, predominantly due to cracking of pavements. All primary roads were functional despite the damage [14].

\section{Lombok Earthquake (July-August, 2018)}

A series of earthquakes recently occurred in Lombok Island, with five major shocks occurring on $29^{\text {th }}$ of July (magnitude 6.4), $5^{\text {th }}$ of August (magnitude 7.0), $9^{\text {th }}$ of August (magnitude 6.2), $19^{\text {th }}$ of August (magnitude 6.5 and 6.9) [31]. In total, there were 571 fatalities and more than 7,700 injuries [31]. Most of the damage was caused to buildings (predominantly houses) and a total cost of US $\$ 528$ million was reported [31]. 


\section{Palu Earthquake (September 28, 2018)}

The latest damaging earthquake experienced by Indonesia is the Palu earthquake which occurred on the $28^{\text {th }}$ of September. It was a very shallow earthquake, with a depth of $10 \mathrm{~km}$ and a magnitude of 7.5. It was also followed by a damaging tsunami with wave heights reaching $7 \mathrm{~m}$ [15]. Based on surveys conducted up until $3^{\text {rd }}$ of October, the number of fatalities has been reported to be over 1400 and more than 2500 injuries [15]. The earthquake and tsunami caused severe damage to houses, buildings, and lifelines [15]. Certain regions experienced significant liquefaction which caused the collapse of buildings and trees. In particular, many roads were damaged or blocked by debris and bridges had collapsed predominantly due to the tsunami forces. The damage to the roadway was reported to cause significant challenges and delays for rescuers and relief aids. Furthermore, the ports near Palu were significantly damaged as well as the Palu airport and therefore only a limited number of planes were able to land and take off for disaster relief purposes. The costs associated with the earthquake and tsunamis have not yet been reported.

\section{Summary and Recommendations}

The current state of the art approach for assessing the seismic performance of infrastructure, namely transportation systems, requires extensive spatial distribution data which needs to be implemented in GIS platforms. Currently there is a tool which is being developed to assess the risk of infrastructure in Indonesia for various forms of natural hazards. However (to the knowledge of the authors), its use for assessing the seismic performance of the transportation system has not been implemented. Such an initiation requires extensive resources including time and money. Thus, it is important that the critical components of the transportation system are implemented and assessed first to ensure the mitigation of risks for future earthquakes.

The reconnaissance of damaging earthquakes which have occurred in Indonesia in the past 20 years indicates that the extent of damage caused to the transportation infrastructure varies greatly. In general, the transportation infrastructure, especially the ones on land, are used immediately after an earthquake even if moderate level of damage takes place. Furthermore, the review of the damage of the transportation infrastructure in Indonesia revealed that the most critical component is bridges (also identified by other studies). The failure and collapse of bridges has the most catastrophic impact on cities because they usually provide the means to cross water bodies and hence alternative routes are limited. Thus, their failure can delay or even prevent disaster relief and response efforts. Furthermore, the failure of bridges can significantly impact the post-earthquake functionality of the city.
In addition, it is observed that landslides cause a high risk after an earthquake. The roadways are often used immediately after an earthquake even if damage has occurred due to landslides since often there are limited alternative routes in regions where landslides occur (for example in mountainous regions). Hence, it is important that prioritisation is given to assessing the seismic performance of roadways near slopes and on embankments. Furthermore, mitigation measures must be taken to reduce the risk of landslides, including re-alignment of roads to safer routes, improvements to drainage of the slopes, use of retaining walls to support fill embankments and to provide protection from landslips and rockfalls, and improved monitoring of slopes.

In addition, the observation of the reported earthquakes in this study indicates that the main damage that has occurred to the transportation infrastructure in Indonesia in the past 20 years has been due to tsunamis induced by earthquakes. This is because strong tsunamis can wipe out regions of a city and there are not many design solutions (in terms of the structural design of the infrastructure) to minimise the effect of tsunamis. The most important mitigation strategy that can be put into place includes warning systems and planned evacuation routes. Therefore, in terms of conducting risk assessment an important aspect (in addition to incorporating the hazard and the vulnerability of the infrastructure) involves assessing the connectivity of the transportation routes with respect to ease and speed of evacuation of residents. Furthermore, since bridges provide important links (usually over water bodies) the assessment of their seismic performance is critical. Regions where the failure of a single bridge can prevent the movement of people to a safe area from tsunamis must be identified and either the seismic resilience of the bridge needs to be improved or preferably alternatives routes must be constructed.

\section{Funding:}

The funding to undertake this study was provided by the Australia-Indonesia Centre (Project Reference IMONWingITB01; Project title: Infrastructure Rapid Start Project).

\section{References}

1. UNISDR \& the World Bank, Synthesis Report on Ten ASEAN Countries Disaster Risks Assessment: ASEAN Disaster Risk Management Initiative, 2010, The International Strategy for Disaster Reduction (ISDR) (United Nations), and the World Bank.

2. Applied Technology Council, ATC 25/FEMA 224: Seismic Vulnerability and Impact of Disruption of Lifelines in the Conterminous United States, in Earthquake Hazard Reduction Series 58. 1991, Applied Technology Council (ATC), Federal Emergency Management Agency (FEMA). 
3. Rosidi, D., Seismic Risk Assessment of Levees. Civil Engineering Dimension, 9(2), 2007, pp. 57-63.

4. Lumantarna, E., Lam, N., and Wilson, J., Seismic Assessment of Structures in Regions of Low to Moderate Seismicity, Civil Engineering Dimension, 14(3), 2012, pp. 156-165.

5. Kappos, A., et al., Seismic Risk of Inter-urban Transportation Networks, Procedia Economics and Finance, 18, 2014, pp. 263-270.

6. Stergiou, E. and Kiremidjian, A.S., Treatment of Uncertainties in Seismic-risk Analysis of Transportation Systems, in PEER Report 2008/02. 2008, Pacific Earthquake Engineering Research (PEER) Center, College of Engineering, University of California, Berkeley.

7. Werner, S.D., et al., REDARS 1: Demonstration Software for Seismic Risk Analysis of Highway Systems, n.d, Federal Highway Administration.

8. Federal Emergency Management Agency (FEMA), Using HAZUS-MH for risk assessment, in FEMA 433 - HAZUS-MH Risk Assessment and User Group Series. 2004: Washington, D.C.

9. Ina SAFE Documentation, 2014 [cited 2018 1/11]; Available from: http://docs.inasafe.org/en/index. html.

10. AHA Centre \& Japan International Cooperation Agency, Country Report Indonesia: Natural Disaster Risk Assessment and Area Business Continuity Plan Formulation for Industralia Agglomerated Areas in the ASEAN Region. 2015, ASEAN Coordinating Centre for Humanitarian Assistance on Disaster Management (AHA Centre), Japan International Cooperation Agency, OYO International Corporation, Mitsubishi Research Institute Inc, CTI Engineering International Co. Ltd.

11. EERI, Learning from Earthquakes: The Northern Sumatra Earthquake of March 28, 2005, 2005, Earthquake Engineering Research Institute (EERI).

12. Central United States Earthquake Consortium, Earthquake Vulnerability of Transportation Systems in the Central United States, 2000, Central United States Earthquake Consortium, Department of Transportation, United States of America.

13. EERI, Learning from Earthquakes: The Mw 7.6 Western Sumatra earthquake of September 30, 2009, 2009, Earthquake Engineering Research Institute (EERI).

14. Collins, L.B., et al., Build Change, AARGI and EERI Earthquake Reconnaissance Report: M6.5 Pidie Jaya Earthquake, Aceh, Indonesia on December 7, 2016. 2017, Earthquake Engineering Research Institute (EERI): Oakland, California.

15. Slawinski, A., et al., Virtual Earthquake Reconnaissance Team (VERT): Immediate Response to M7.5 \& Tsunami, Palu-Indonesia, October 2018, 2018, Earthquake Engineering Research Institute (EERI).
16. Saatcioglu, M., Ghobarah, A., and Nistor, I., Effects of the December 26, 2004 Sumatra Earthquake and Tsunami on Physical Infrastructure, ISET Journal of Earthquake Techno$\log y, 42(4), 2005$.

17. Abercrombie, R.E., Antolik, M., and Ekström, G., The June 2000 Mw 7.9 Earthquakes South of Sumatra: Deformation in the India-Australia Plate, Journal of Geophysical Research, 108(B1), 2003. pp. 6-16.

18. UN Office for the Coordination of Humanitarian Affairs. UNDAC Team Mission Report Bengkulu Earthquake, Sumatra, Indonesia 6-16 June 2000. 2000 [cited 2018 1/11]; Available from: https://reliefweb.int/report/indonesia/undacteam-mission-report-bengkulu-earthquakesumatra-indonesia-6-16-jun-2000.

19. The World Bank, Indonesia: Advancing a National Disaster Risk Financing Strategy - Options for Consideration, 2011, Global Facility for Disaster Reduction and Recovery (GFDRR), The International Bank for Reconstruction and Development/The World Bank.

20. The Consultative Group on Indonesia, Indonesia: Preliminary Damage and Loss Assessment - the December 26, 2004 Natural Disaster. 2005, BAPPENAS and the International Donor Community.

21. WHO, Emergency Situation Report No. 16, 18 May 2005: Earthquake in North Sumatra Province and NAD Province, Indonesia. 2005, World Health Organization (WHO), Indonesia.

22. The Consultative Group on Indonesia, Preliminary Damage and Loss Assessment: Yogyakarta and Central Java Natural Disaster. 2006, National Development Planning Agency (BAPPENAS), the Yogyakarta and Central Java Provincial Development Planning Agencies (BAPEDAs), International Partners.

23. Reese, S., et al., Tsunami Vulnerability of Buildings and People in South Java - Field Observations after the July 2006 Java Tsunami, Natural Hazards and Earth System Sciences, 2007, pp. 573-589.

24. Muhari, A., Diposaptono, S., and Imamura, F., Toward an Integrated Tsunami Disaster Mitigation: Lessons Learned from Previous Tsunami Events in Indonesia, Journal of Natural Disaster Science, 29(1), 2007, pp. 13-19.

25. Mori, J., et al., The 17 July 2006 Tsunami Earthquake in West Java, Indonesia, Seismological Research Letters, 78(2), 2007.

26. EERI, Learning from Earthquakes: Observations on the Southern Sumatra Earthquake of September 12-13, 2007. 2007, Earthquake Engineering Research Institute (EERI).

27. Aydan, O., et al., A Reconnaissance Report on the Bengkulu Earthquake on September 12, 2007. 2007, Japan Society of Civil Engineers (JSCE), Japan Association for Earthquake Engineering (JAEE), Andalas University and KOGAMI 
28. BNPB, West Sumatra and Jambi Natural Disasters: Damage, Loss and Preliminary Needs Assessment. 2009, Government of Indonesia's National Disaster Management Agency (BNPB), with vital input from the National Development Planning Agency (Bappenas), the Provincial Governments of West Sumatra and Jambi, and International Partners.

29. EERI, Learning from Earthquakes: Indonesia Earthquake and Tsunami, 2010, Earthquake Engineering Research Institute (EERI).
30. Mullen, J. and Quiano, K., Death Toll in Indonesia Quake Rises to 35; Rescuers Search for Missing, 2013 [cited 2018 1/11]; Available from: http://edition.cnn.com/2013/07/04/world/asia/indonesia-earthquake/index.html.

31. AHA Centre, The 2018 Lombok Earthquake, Indonesia, in Situation Update, No. 8, 2018, ASEAN Coordinating Centre for Humanitarian Assistance on Disaster Management (AHA Centre). 